\title{
Can Asia provide models for tax-based European health systems? A comparative study of Singapore and Sweden
}

\author{
Richard B. Saltman ${ }^{1 *}$ (D), Ming-Jui Yeh² (D) and Yu Liu ${ }^{1}$ \\ ${ }^{1}$ Department of Health Policy and Management, Rollins School of Public Health, Emory University, 1518 Clifton Rd NE, \\ Atlanta, GA 30322, USA and ${ }^{2}$ Department of Health Policy and Management, College of Public Health, National Taiwan \\ University, No. 17, Xuzhou Road, Zhongzheng District, Taipei City, 100, Taiwan \\ *Corresponding author. Email: rsaltma@emory.edu
}

(Received 12 December 2019; revised 12 August 2020; accepted 2 October 2020; first published online 16 November 2020)

\begin{abstract}
Singapore's health system generates similar levels of health outcomes as does Sweden's but for only $4.4 \%$ rather than $11.0 \%$ of gross domestic product, with Singapore's resulting health sector savings being redirected to help fund both long-term care and retirement pensions for its elderly citizens. This paper contrasts the framework of financial risk-sharing and the configuration and management of health service providers in these two high-income, small-population countries. Two main institutional distinctions emerge from this country case comparison: (1) Key differences exist in the practical configuration of solidarity for payment of health care services, reflecting differing cultural roots and social expectations, which in turn carry substantial implications for financing long-term care and pensions. (2) Differing arrangements exist in the organization of health service institutions, in particular balancing public as against private sector responsibilities for owning, operating and managing these two countries' respective hospitals. These different structural characteristics generate fundamental differences in health sector financial and delivery outcomes in one developed country in Far East Asia as compared with a well-respected taxfunded health system in Western Europe. In the post-COVID era, as Western European policymakers find themselves forced to adjust their publicly funded health systems to (further) reductions in economic growth rates and overall tax receipts, and as the cost of the information revolution continues to rise while efforts to fund better coordinated social and home care services for growing numbers of chronically ill elderly remain inadequate, this two-country case comparison highlights a series of health system design questions that could potentially provide alternative health sector financing and service delivery strategies.
\end{abstract}

Key words: Comparative health systems; health sector solidarity; health system financing; long-term care funding; public hospital management; Singapore health system; Sweden health system

\section{Introduction}

An intriguing observation when one looks across developed health systems is that East Asian systems (except for Japan) spend substantially lower gross domestic product (GDP) percentages on health care than do nearly all Western European systems. Equally noticeable is that, despite these lower expenditures, medical outcomes and health status in these developed Asian health systems are broadly equal to or better than those found in their more expensive Western European counterparts.

This counter-intuitive relationship - substantially higher Western European health expenditures yet equivalent East Asian clinical and epidemiological outcomes - can be clearly seen in standardly available international data.

As Table 1 indicates, total expenditure in the four developed Asian health systems (all figures are purchase power parity adjusted) ranged from 4.4\% of GDP (2017) in Singapore (5.6 million 
Table 1. Percentages of total health expenditure in GDP and epidemiological outcomes in Developed Asian and European health systems

\begin{tabular}{|c|c|c|c|c|}
\hline Health system & $\begin{array}{l}\text { Percentages of } \\
\text { total health } \\
\text { expenditure } \\
\text { in GDP (2018) }\end{array}$ & $\begin{array}{c}\text { Colon cancer } \\
\text { 5-year net survival } \\
(2010-2014)(\%)\end{array}$ & $\begin{array}{l}\text { Breast cancer } 5 \text {-year } \\
\text { relative survival } \\
(2010-2014)(\%)\end{array}$ & $\begin{array}{l}\text { Life expectancy } \\
\qquad(2018)\end{array}$ \\
\hline \multicolumn{5}{|c|}{ Developed Asian health systems } \\
\hline Singapore & $4.4(2017)$ & 60.3 & 80.3 & 83 \\
\hline Japan & 10.9 & 67.4 & 88.9 & 84 \\
\hline Taiwan & $6.3(2016)$ & NA & NA & 80 \\
\hline South Korea & 8.1 & 69.5 & 85.8 & 83 \\
\hline \multicolumn{5}{|c|}{ Northwestern European health systems } \\
\hline UK & 9.8 (estimated) & 59.7 & 85.6 & 81 \\
\hline Sweden & 11.0 & 66.1 & 88.8 & 83 \\
\hline Germany & 11.2 & 66.3 & 85.7 & 81 \\
\hline The Netherlands & 9.9 & 64.5 & 86.1 & 82 \\
\hline
\end{tabular}

Source: https://stats.oecd.org/, https://data.worldbank.org/, and Ministry of Health and Welfare, Taiwan (12).

population) to $6.3 \%$ (2016) in Taiwan (23.8 million population) and 8.1\% (2018) in South Korea (51 million population) to $10.9 \%$ (2018) in Japan (126.8 million population). In comparison, the equivalent 2018 numbers for key western European health systems show consistently higher figures, from $9.8 \%$ for the UK and $11.0 \%$ for Sweden (for tax-funded health systems) to $9.9 \%$ for The Netherlands and 11.2\% for Germany (for social-health-insurance funded health systems) (OECD, 2017; Yoong et al., 2018).

Yet, Table 1 also shows clinical outcomes and epidemiologic data for developed East Asian health systems that are broadly equivalent to those for Western European countries. Life expectancy figures range from age 80 to 84 in the Asian systems, compared with 81.1 to 83 in the European ones. Five year survival rates for cancer care - a sentinel outcome both clinically and politically - are slightly better in East Asia (except for Taiwan) for colorectal cancer (60.3 to $69.5 \%$ as compared with 59.7 to $66.3 \%$ ) and roughly equal (including Taiwan) for breast cancer ( 80.3 to $88.9 \%$ as compared with 85.6 to $88.8 \%$ ).

These observed differences in health sector expenditure and performance between East Asian systems such as Singapore, Japan, Taiwan and South Korea, in comparison with tax-funded European systems such as Sweden and England, and also social-health-insurance-funded systems such as the Netherlands and Germany, reflect inter-related political, cultural and institutional as well as economic and financial factors (Oliver and Mossialos, 2005; Saltman, 2018). The impact of these factors was compounded in much of Western Europe by the recessionary post-2008 fiscal crisis environment, placing health systems under heavy financial pressure at the same time that they needed to meet rapidly developing international standards for new technology and effective treatment of major life-threatening conditions such as cancers and heart disease (Donnelly, 2019; Saltman, 2019).

In this complicated policymaking context, the two above-detailed data-based comparisons between developed Asian and Western European health systems suggest a series of core institutional questions. A central underlying issue is whether developed Asian systems have put in place mechanisms for financing and operating contemporary health care systems that are more clinically efficient and more policy effective than those currently in use particularly in tax-funded Western European countries. 
Funding strategies for developed country health systems have received extensive academic attention since the 1990s (Glaser, 1991; Saltman and Figueras, 1997; Mossialos et al., 2002). Recent years have seen increasing concern about the need for additional funding for Western European health systems, particularly for predominantly tax-funded systems similar to that in Sweden (Thomson et al., 2015; Saltman, 2015a, 2019). In 2019, the European Observatory on Health Systems and Policies in Brussels published two policy analyses on aging societies, calling for more diverse funding sources for European health systems (Cylus et al., 2019a, 2019b). Direct calls for higher taxes and more public funds have also been made by other prominent European public health figures (Modi et al., 2018).

Interest in more efficient management of publicly owned hospitals and of the public hospital sector has been prominent since the early 1990s in both developed country (Culyer et al., 1990; Hood, 1991; Saltman and von Otter, 1992) and also developing country (Preker and Harding, 2003) settings. Subsequent research has suggested that semi-autonomous management strategies can improve financial efficiency as well as patient satisfaction in publicly owned hospitals (Saltman et al., 2011). Simultaneously, however, opposition to adopting private sector style management tools for public hospitals has grown in some tax-funded health systems, in particular Sweden (Dahlgren, 2014), which also has seen national government efforts to constrain the role of privately capitalized elderly care facilities (Winblad et al., 2017).

Over the past decade, better clinical coordination between primary and hospital care, on the one hand, and hospital and social/long-term care, on the other, has become a major topic of health sector as well as academic concern (Genet et al., 2012). Integrated and/or coordinated care is seen as an effective strategy to reduce rapidly growing publicly funded costs for caring for multiple chronically ill elderly (Busse et al., 2010). These financial concerns have intensified as the number of elderly in developed countries has grown.

\section{Comparing health systems of Singapore and Sweden}

This paper contributes to the long-running health system debate described above about improving health system funding and delivery by providing a detailed case study of two high-income, small-population countries: one Asian - Singapore; and the other Western European Sweden. It compares the two countries differing mechanisms of health sector funding, the implications for more efficient use and management of health provider resources, and the potential to free up existing health-related funding for use by elderly citizens for both pensions and long-term care. In so doing, the case study also considers the formative role that national culture plays in shaping each citizenry's policy expectations and patient behavior.

The general pattern of lower costs but similar demographic and clinical outcomes in developed East Asia is particularly apparent when one looks at what is the lowest spending developed health system in Asia, which is Singapore. Recent interest in Singapore's health sector arrangements has however been rather sparse: a 2001 article with three short commentaries (Barr, 2001; Ham, 2001; Hsiao, 2001; Pauly, 2001), a 2003 chapter in a World Bank volume (Phua, 2003); more recently a 2013 review of the Singapore health system (Haseltine, 2013), followed by a short, dismissive editorial (McKee and Busse, 2013).

Both Singapore and Sweden have relatively small, homogeneous populations - Singapore has 5.6 million population, of which $74.3 \%$ are ethnic Chinese (DOS, 2018), while Sweden has nearly 10.2 million people, of whom $80 \%$ are ethnic Swedes. However, Table 2 reveals a complex set of demographic statistics that suggest Sweden's substantially higher health care costs may be only partially related to its number of older inhabitants. Singaporean citizens (e.g. those who fully participate in Singapore's medical savings account system) make up approximately the same percentage of younger age groups (20.9\% are under age 20 to Sweden's $18 \%$ under age 15, with $63.1 \%$ under age 66 compared with Sweden's $62 \%$ under age 65). Sweden does have a small but significantly higher number of more elderly inhabitants $-20 \%$ over 
Table 2. Selected statistics for Sweden and Singapore, 2018 and 2019 data

\begin{tabular}{|c|c|c|}
\hline & Sweden & Singapore \\
\hline \multicolumn{3}{|l|}{ (a) Population } \\
\hline Total population as of 2018 & $10,183,175$ & $5,638,676$ \\
\hline Percentage of population ages $0-14$ as of 2018 & 18 & - \\
\hline Percentage of population ages $15-64$ as of 2018 & 62 & - \\
\hline Percentage of population ages $65+$ as of 2018 & 20 & - \\
\hline Percentage of population ages 80 and above as of 2019 & 5.2 & - \\
\hline \multicolumn{3}{|l|}{ (b) Citizens, permanent residents, and temporary workers } \\
\hline Total number of citizens in 2019 & - & $3,500,900$ \\
\hline Total number of permanent residents in 2019 & - & 525,300 \\
\hline Total temporary and non-permanent residents in 2019 & & $1,677,400$ \\
\hline Percentage of citizens ages $0-19$ as of 2019 & - & 20.9 \\
\hline Percentage of citizens ages $20-65$ as of 2019 & - & 63.1 \\
\hline Percentage of citizens ages $65+$ as of 2019 & - & 16 \\
\hline Percentage of citizens aged 80 and above as of 2019 & - & 3.2 \\
\hline Number of persons who have acquired citizenship in 2019 & 64,206 & 15,000 to 25,000 \\
\hline Foreign worker permits issued in 2008 & 50,000 & 253,800 \\
\hline \multicolumn{3}{|l|}{ (c) Additional data } \\
\hline Percentage of adults who own their homes in 2018 & 64 & 91 \\
\hline Unemployment rate in 2018 & $6.30 \%$ & $3.77 \%$ \\
\hline
\end{tabular}

Source: https://data.worldbank.org/country/sweden; https:/www.statista.com/statistics/378643/unemployment-rate-in-singapore/; https:// www.mom.gov.sg/documents-and-publications\#/?page=1\&q=\&facet=category\&category=Statistics; https://www.thelocal.se/20200109/heresa-look-at-who-got-a-work-permit-in-sweden-last-year; https://www.statista.com/statistics/664518/home-ownership-rate-singapore/; https:// tradingeconomics.com/sweden/home-ownership-rate; https://www.scb.se/en/finding-statistics/statistics-by-subject-area/population/ population-composition/population-statistics/; https://www.strategygroup.gov.sg/files/media-centre/publications/population-in-brief-2019. pdf; https://sweden.se/society/elderly-care-in-sweden/; https://www.statista.com/statistics/624913/singapore-population-by-age-group/.

age 65 and 5.2\% over age 80 - in comparison with older Singaporean citizens with $16 \%$ over age 65 and $3.2 \%$ over age 80 .

Regarding numbers of non-citizens (who in Singapore have differing relationships to the health financing system, as detailed in the next section), Singapore issues many more foreign work permits than does Sweden however Sweden's foreign workers (whether manual and professional) often come from elsewhere in the European Union, do not require work permits, and do not show up in permitting statistics. Additionally, a (non-EU) work permit in Sweden continues to be difficult to obtain and difficult to keep (The Local, 2018).

Finally, regarding refugees, Sweden, a geographically expansive - and in its interior, sparsely populated - country, has taken in several hundred thousand refugees coming from Latin America in the 1980s, Bosnia in the 1990s, as well as more recently from various Middle Eastern countries. Quite differently, Singapore - a geographically tiny country located in a politically volatile part of the world - generally does not accept refugees.

Both countries have had periods in which they were seen internationally as role model health systems for other countries' governments to study - Sweden in the 1980s; Singapore more recently. In a symbolic turn of events, in 2018 the Swedish government's Department of Innovation (Vinnova) sent a high-level delegation of Swedes to visit Singapore, with the express 
purpose of better understanding how technology that has been introduced in the Singaporean health system might be utilized in the Swedish system (Eriksson et al., 2019).

A key observation that underlies this case study is that Singapore has become a source for new health policy ideas adopted by other countries seeking more effective and efficient health care systems. One of the more attractive international concepts for funding health care services in a fiscally constrained financial future is that of medical savings accounts. As discussed below, a rapidly developing Singapore in 1984 was the first country to implement such a system on a nationwide basis (Barr, 2001). Subsequently, this Singaporean funding concept has become increasingly central in two of the world's largest health care systems. In 1998, People's Republic of China structured its new health insurance program for urban workers on a variation of the Singaporean medical savings account model (PRC, 2012). In 2003, the United States' federal government introduced an optional variation on Singapore's medical savings account system of paying for health care services in the Medicare Prescription Drug, Improvement, and Modernization Act, replacing a previous medical saving account system with a new tax-free system of Health Savings Accounts (H.R.1).

Thus the core concept of Singapore's health system payment approach has served as a model for two countries that have populations of 320 million (United States) and 1.3 billion (China), that have the world's no. 1 and no. 2 largest economies by GDP, and that had two of the world's fastest growing economies in the decade prior to the onset of the COVID-19 pandemic. This is a notable accomplishment for a small island nation of 5.6 million people, suggesting that the core funding concept it developed has broader applicability and can be expected to support strong economic growth.

Equally important - and potentially equally attractive for policymaking purposes in taxfunded Western European countries - the Singapore model of health savings accounts directly links incentives to reduce spending in the health sector to increased savings for retirement pensions. Combined with the ElderShield program that provides individually-paid long-term care insurance (see below), Singapore's health funding model also takes a major step in reducing public sector revenues needed to pay for elderly care services.

Singapore further pioneered two additional provider-side concepts that have become important in other developed country health systems. In 1987, Singapore combined its 15 publicly owned and operated hospitals, which provide $80 \%$ of all hospital beds in the country, into a single independent public corporation, the Hospital Corporation of Singapore, which is independently managed - e.g. free of direct political interference - but remains publicly accountable for its results both fiscally and in clinical outcome terms (Ramesh, 2008). Similar semi-autonomous private-style management strategies for what remained publicly owned hospitals have since been implemented in a number of European health systems, starting with the UK in 1991, and spreading in various forms and degrees through other developed European systems during the 1990s and early 2000s including Italy, Spain, Norway, Estonia and Czech Republic (Saltman et al., 2011).

The second hospital management mechanism pioneered in Singapore that has subsequently been adopted elsewhere was the concept of transparent pricing for hospital services. The Transparency Reform of 2003 required all hospitals (public and private) to update their pricing structure for services online every month, with the expectation that this would enable patients to make better decisions about how to commit funds from their health savings accounts $(\mathrm{MOH}$, 2007). The logic was that of the private market: posted pricing would encourage hospitals to worry about their competitive position vs other institutions, and act as a damper on price increases (Kessler and McClellan, 2000; Cooper et al., 2019). Similarly, the holder of a medical savings account could become more of an informed purchaser, and less likely to demand overly expensive or medically unnecessary services (Buntin et al., 2006; Dody, 2014).

This concept of requiring hospitals to post prices for their services has now been adopted in the United States in June 2019, with an executive order requiring a similar set of hospital pricing 
notifications in all hospitals. This is intended to improve patient choice decisions - primarily for elective and outpatient procedures - especially for individuals with high-deductible health insurance plans under the 2010 Affordable Care Act as well as those privately insured with (what have been renamed in the United States) Health Savings Accounts.

Thus three important characteristics of the Singaporean health system have since been adapted for use in other developed countries: medical savings accounts, semi-autonomous operating structures for public hospitals and mandatory posted pricing for hospital services. Taking advantage of the uniqueness of the Singaporean health system, this paper explores core underlying policy implications that emerge from comparative analysis of Sweden and Singapore, focusing on funding arrangements, the delivery model in hospital governance and the different cultural roots and social expectations in which these two health systems are embedded.

A caveat here is that reflecting space limitations this paper focuses only on financing, access to and delivery of curative clinical services. As such it does not assess the scale, scope or implications of these two countries' preventive policies and measures regarding health or social care services.

\section{Comparing the two health systems}

\subsection{Differing forms of risk-sharing}

A central distinction between the Swedish and the Singaporean health systems is their differing notions and applications of the concept of solidarity. Solidarity has traditionally been understood in Western European health systems as an equal sharing of financial risk among all the participant members of the solidarity community (Houtepen and ter Meulen, 2000; Saltman and Dubois, 2004; Yeh, 2019). In practical terms in developed countries, solidarity has multiple sources, and may be strengthened or weakened depending on the economic capacity of its specific guarantors (Saltman, 2015b).

\subsection{Institutional solidarity in Swedish health system}

In the Swedish case, currently, solidarity in the sharing of risk for funding publicly provided health and social services is predominantly provided through three separate levels of publicly levied taxes (Anell et al., 2012):

(a) Regional: A flat-rate tax assessed by each of 20 county or regional councils - typically $14 \%$ of all earned income above a small deductible funds approximately $80 \%$ of total costs of public hospital and primary care, chronic care and alcohol-related services.

(b) Municipal: A flat-rate tax assessed by each of 295 municipal governments - typically $17 \%$ of all earned income above a small deductible, to pay for multiple municipal services including a substantial portion (minus mandatory co-payments) of nursing home and home care services.

(c) National: A scaled income tax of up to $50 \%$ on all earned and a sliding portion of investment income. In addition, the Swedish government levies a $25 \%$ value-added tax (VAT) on all purchases and services across the entire economy, including food and clothing. Although most health and social care costs are paid for from county and municipal taxes, the national government contributes additional funds for cross-constituency equity balancing and certain prioritized medical programs.

In aggregate, the three levels of Swedish government together provide public tax-based funding flat-rate (regional and municipal) and size-of-income-scaled as well as value-added and property taxes (national) - of $84 \%$ of total Swedish health expenditures (Data, 2019). 
In addition, Sweden has three privately paid sources of what is also risk-sharing for health funding and thus what is also practically speaking a functional form of solidarity among insurance participants:

(d) Occupational: National-government-mandated company provision (including public sector agencies) of specified workplace-related services, including primary care services, for full- and half-time employees, paid for by the business, provided either at the worksite by private providers or at contractually paid county-council-run primary health centers.

(e) Private-company-provided, private health insurance policies: A number of private companies purchase private commercial health insurance for curative primary and elective care for their employees. Although these policies are also purchased by some large well-capitalized businesses, past research starting in the 1980s (Rosenthal, 1986) demonstrated that often these policies are purchased by smaller companies seeking to insure that senior executives critical to the company's survival would, if they became ill, be able to jump the long queues for elective public hospital procedures and get back to work as soon as possible (Anell et al., 2012).

(f) Private individually purchased health insurance policies: These are individual citizens choosing to buying separate (supplemental) private health insurance policies, for example for cancer care which has had long queues for many years in Sweden.

The combined total for private insurance coverage of (e) and (f) is currently estimated at over 600,000 policies in a country of 10 million citizens (Barkman, 2017), up from 382,000 in 2010 (Anell et al., 2012). The Swedish government has actively discouraged the purchase of additional private cover since 1988 when it removed the income tax deductibility of privately purchase health insurance policies (Anell et al., 2012).

\subsection{Institutional solidarity in Singaporean health system}

In the Singaporean case, currently, there are two forms of mandatory public solidarity:

(a) MediSave: This is a national system of medical savings accounts, imposed by law, funded by mandatory pre-tax deductions from an employed persons' salary (Haseltine, 2013) (additional voluntary contributions are not pre-tax). These accounts are administered by the same national government agency, the Central Provident Fund Board (CPFB) that administers the national pension system (CPFB, 2018). In 2017, each employed individual whose monthly wage was $\$ 750$ (about $\$ 550$ in USD) or more was required to automatically contribute, depending on age, $1 \%$ (if above age 65) to 23\% (if age 35 or below) of earnings (CPFB, 2019). These funds are automatically placed in that individual's personal account, maintained by the national (pension agency), and paid a specified level (by law) of interest for funds that are not withdrawn or otherwise invested in approved assets such as conservative stock funds (Haseltine, 2013).

The amount automatically deducted from salary rises as an individual's salary rises. Once the total balance in an individual's medical savings account reaches a specified level for that person's age (currently 57,000 Singapore dollars, about 41,000 USD, for an individual who reaches age 65 in 2019), then all further deposits (which continue as long as the person is employed), or investment earnings, are - again automatically - transferred to that person's (also mandatory) nationally administered individual retirement account (which each individual also owns and can leave to heirs) which can be invested in approved assets once the total reaches an age-specified amount (Singapore CPF website).

Funds can be withdrawn from these accounts to pay for listed medical costs (hospital, primary care and home care), not only for the account holder, but also for any member of the account 
holder's direct family. Funds beyond an age-tied balance also can be used toward buying a home, which is seen as 'vital for political and social stability' (Haseltine, 2013, p. 4). Table 2 shows that $91 \%$ of Singaporean citizens own their own homes, in contrast to $64 \%$ of Swedes.

An essential aspect of the attractiveness to citizens of these mandatory publicly-collected and managed accounts, and of their impact on health care utilization, costs and prices, is that all funds that remain un-used in an individual's medical savings account when that person dies (exactly as in their mandatory individual retirement account) are automatically inherited by that person's heirs, and - crucially - on a tax-free basis (Barr, 2001; Haseltine, 2013). Thus there are strong incentives built into the medical savings account system for each working adult to be careful with how he utilizes services provided by the Singapore health care system, and to try to treat minor and less-serious events in the least expensive manner.

(b) MediFund: This is a wholly publicly funded safety net for low-income individuals who do not have sufficient medical savings account balances to pay for necessary services. Individuals must send their applications to an independent MediFund Committee at each provider institution in order to have their care paid by this fund. Clinical services provided by this public fund are of the same standard as for self-paying individuals, however hotel services are provided only on a non-air-conditioned 12-bed ward basis (Haseltine, 2013).

The above two public mandatory systems of risk-sharing for health care costs in Singapore are supplemented by one public and two private, voluntary, risk-sharing insurance-based arrangements:

(c) MediShield: This is a publicly offered but optional medical insurance plan to help pay for prolonged illnesses that may require long-term treatment, such as kidney dialysis or some cancer treatments. Individuals are automatically enrolled unless they opt out - less than $10 \%$ of the population chose not to be covered - and enrollment must take place before age 75. Annual premiums are relatively low, increasing with age and can be paid from the individual's MediSave account. There is an annual deductible, and outpatient services have a fixed $20 \%$ co-payment before benefits apply (Haseltine, 2013).

The Singaporean government has proposed to replace the voluntary MediShield framework in 2020 with a comprehensive, mandatory program of long-term care coverage called CareShield Life, which all citizens over age 21 will be required to hold and pay.

(d) ElderShield: This is voluntary private insurance for long-term disability, established by the national government in 2002 to help individuals cover the costs of nursing homes and long-term care. All individuals are enrolled at age 40, paying annual premiums until they reach age 65. Individuals are enrolled in one of the three different private insurance company plans as selected by the Ministry of Health (MOH, 2018b). Although formally voluntary in the sense that individuals can choose to opt out, some $80 \%$ of Singaporean citizens aged above 40 choose to pay the premiums to carry this coverage ( $\mathrm{MOH}, 2018 \mathrm{~d}$; DOS, 2019). Premiums can be paid with MediSave or with private funds ( $\mathrm{MOH}, 2018 \mathrm{a})$. Individuals can also buy supplements that have higher payouts (MOH, 2018c).

(e) Private commercial insurance: Many Singaporean citizens also choose to purchase individual private health insurance called Integrated Shield Plans, which can be paid by savings in their MediSave account. Although these insurance plans are offered by private companies, the benefits are all identical, regulated by the government. These plans cover costly services that are not payable through MediSave (CPFB). In addition to the Integrated Shield Plans, Singaporean citizens can also purchase other private health insurance policies. 
Beyond this framework of individual contribution-based framework, the Singaporean government directly injects substantial public subsidies into essential and/or expensive hospital, medical and pharmaceutical services, with higher subsidies provided to lower income citizens (Haseltine, 2013). These public revenues - collected primarily through income and sales taxes - amounted to $48.2 \%$ of total health expenditures in 2017 (World Bank, 2020).

Three additional funding points further flesh out Singapore's health sector funding approach. The first two concern the treatment of immigrants. Permanent residents are required to participate in the MediSave system, with the proviso that, if they leave the country permanently, they can take their account balances with them. Thus these immigrants contribute directly to the solvency of the overall MediSave program. The only difference is that permanent residents receive only $50 \%$ of the direct public subsidy for essential hospital, medical, and pharmaceutical services (Haseltine, 2013).

The second point is that temporary residents with work permits must have private health insurance bought for them by their employers, purchasing strictly regulated policies that must provide Singapore $\$ 15,000$ of medical coverage (Haseltine, 2013). This privately paid insurance providing access to high-quality medical care, coupled with relatively high pay levels and an individual monthly government 'assistance' payment of Singapore $\$ 750$ for living costs (Li, 2020), makes working in Singapore very attractive compared with most workers' home countries.

A third point concerns foreign patients who travel to Singapore for a specific procedure. Singapore's combination of high quality and relatively low medical costs attracted an estimated 500,000 international patients in 2018, paying full charges, resulting in about $4 \%$ of total hospital income (Medical Tourism Singapore, 2020). This 'medical tourism' thus provides a small but noticeable degree of external cross-subsidization for infrastructure operating costs in the Singapore hospital system.

In solidarity terms, therefore, the Singaporean model represents a mixed system of individual and collective forms of financial responsibility, in which a bit more than half of all funding is private (although predominantly mandatory) funds, while a little less than half is public tax funding (World Bank, 2020). Within this global framework, a notable second characteristic is that Singapore's funding system applies four different levels of public sector subsidy payments to help defray charges for individual medical services: full subsidy level for citizens; half subsidy level for permanent residents; $0 \%$ subsidy level for foreign patients and a separate, substantially higher subsidy level for low-income individuals (Haseltine, 2013).

As Table 3 demonstrates, this privately sourced funding figure of $51.8 \%$ of total health expenditure in Singapore is nearly triple that of Sweden's privately sourced health funding percentage of $16.3 \%$. Conversely, in 2017, in purchasing power parity adjusted figures, the government of Singapore spent 2058 USD of public tax funding per inhabitant for health services, while the government of Sweden spent more than double that amount of public funds, or 4770 USD, with both countries achieving quite similar clinical and epidemiological outcomes.

\section{Policy implications}

Two main policy-related distinctions can be drawn from the two-country comparison above. Although these observations apply first and foremost to the countries involved, they also serve to raise larger issues for health systems development generally, and potentially for the near and medium-term future across fiscally-straitened tax-funded health systems in Western Europe (Alesina and Giavazzi, 2008; Saltman and Cahn, 2013; Thomson et al., 2015).

First: Differences in the practical structure of responsibility and solidarity for payment of health care services in these two countries, reflecting differing cultural roots and social expectations.

Singapore: In Singapore, the concept of responsibility begins directly with the individual him- or herself. Beyond that personal level of responsibility lies, as the second layer of protection, the 
Table 3. 2017 health expenditures Sweden and Singapore

\begin{tabular}{lcc}
\hline & Sweden & Singapore \\
\hline \% GDP on health expenditure & 11.02 & 4.44 \\
\hline Total per capita health expenditure (USD) & 5699.61 & 4269.96 \\
\hline Total health care expenditure from government & 83.69 & 48.20 \\
\hline Per capita total government health care expenditure (USD) & 4770.28 & 2058.31 \\
\hline
\end{tabular}

Source: https://data.worldbank.org/.

All USD adjusted for PPP.

concept of solidarity, but solidarity that begins at the family level, between immediate family members and then also among more extended brothers/sisters/aunts/uncles. In this sense, solidarity merges with the level of individual private and personal responsibility. Although this private family solidarity is supplemented - for varying services and in varying degrees - by a range of government-generated public subsidies, the public sector plays a secondary rather than a primary role in the construction of practical day-to-day social support.

The fundamental focus of health policymaking for financing health care services in Singapore is to generate individual and family-based, private-sector (or civil society) levels of financing and accountability. The core policy expectation here is that, by placing first and foremost emphasis on each individual's personal and family responsibility, it will be easier and more efficient for society and/or the government to meet the necessary core requirements (e.g. public funding for certain hospital services) as well as additional needs of lower income citizens. Equally important, the large role for publically mandated but privately controlled funding creates incentives to not spend money unnecessarily, whether that might mean more expensive and/or unnecessarily long hospital stays, duplicative medical services and procedures, brand-name rather than generic pharmaceuticals (both inpatient and outpatient) and numerous other examples of discretionary medical decision-making that are unlikely to affect clinical outcomes but which can have substantial effects on the total cost of care.

Lee Kuan Yew, the former long-serving Prime Minister of Singapore, explained this approach to health policymaking by suggesting it is consistent with two fundamental characteristics of moral culture in Far East Asian societies generally: Confucian ethics and family responsibility (Zakaria and Lee, 1994). Lee repeated the traditional Confucian political thought that later became a folk-wisdom phrase and which lies behind Singapore's approach to structuring social programs (originated from the Confucian classic Great Learning or Daxue, 大學) (Zakaria and Lee, 1994: 113-114):

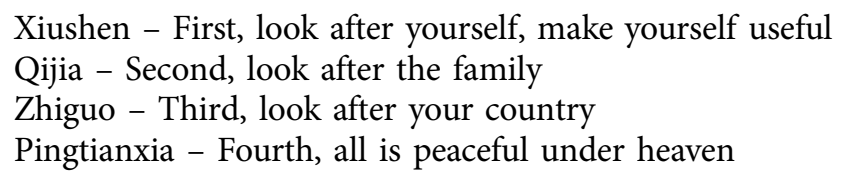

Thus in Singapore's system of health care financing, the individual and then the family take preeminence - indeed are required to take pre-eminence under the State-enforced structure of medical savings accounts (McKee and Busse, 2013). Subsequently, there are further 'fall-back' lines of, first, volitional self-selected private insurance risk pools (e.g. MediShield), followed by additional private commercial insurance policies, and, as a last resort, if needed, public tax-funded welfare state funds (MediFund). Focusing on the family as the building block for social programs also is consistent with the deep-seated traditional economic framework in much of Asia, where familybased farm operations were at the heart of the economy. Overall, most decisions about paying for health care services, up to the level of catastrophic hospital care, are made for most Singaporeans 
by themselves and/or a member of their immediate family, rather than by a level or agency of government. Looking at risk-based pooling (as against individual out-of-pocket expenses), then, one can conclude that in Singapore there are four different levels of practical financial solidarity, in which only the fourth, last form - MediFund - is fully public sector tax-payer funded.

Sweden: The conceptual approach to solidarity in Sweden has been quite different, following along on traditional lines of social democratic welfare-state principles (Korpi, 1983). In Sweden, these principles were consolidated under the general principles of 'Folkhemmet', introduced after the Social Democrats were first elected to national power in 1932. In this view, solidarity is a strictly public sector concept, uniting each separate individual with the agencies and instruments of government (municipal, regional and national), by assuring all individuals that the public sector will provide the necessary funding and, in the case of the tax-funded health systems of Northern Europe such as Sweden, the required publicly operated health services, to meet all legitimate medical needs of every Swede. In this view, solidarity in health care is the same - indeed an integral part of - solidarity in social and home services, disability coverage, occupational services, housing allowances, child care services, monthly cash child stipends, university tuition, university living costs and a wide range of additional State-mandated and State or local-government funded services (Korpi, 1983; Saltman and von Otter, 1992).

This concept of 'folkhem' was conceived as a 'halfway' measure between socialism and capitalism, encompassing not just health care but all welfare state services as well as education, arts and culture, reflecting standard Socialist rhetoric about the political importance of controlling the content of education and culture (Lindbom, 2001). In this traditional Socialist view of the world, there was little perceived role for family responsibility (Landsorganization, 1990). Indeed, the Swedish Social Democratic Party saw itself as providing at least some of the personal development that traditionally had been the responsibility of the nuclear family, a perspective that continues to be carried out both in party organizations and youth groups as well as in core public sector institutions and services such as Dagis (day care centers for all infants and pre-elementary age children) and the programs and centers of Fritidsgard (secondary student free-time centers).

Thus, in Sweden's system of health care financing, there is little role for individual responsibility, beyond small annual co-payments for primary care and outpatient prescriptions, both of which are limited by Parliamentary decision to a total of 3350 SEK or about 335 USD per 12 month period (Sweden.se, 2018).

Instead, preponderant financial responsibility is lodged with public sector tax funds, with decision-making about the expenditure of those funds being made by a mix of politically elected and administratively appointed public sector officials.

The concept of equality that undergirds this public role has both strengths and weaknesses. The strengths revolve around the sense of security - trygghet, in Swedish - that lies at the core of the Folkhem concept. No Swede worries that they will not be able to afford to pay for the medical services they need.

Conversely, however, this public guarantee comes with reservations and conditions. Sweden has had, since the late 1980s, growing funding problems for publicly provided health care at the county council level (which provides all hospital and - until 2007 all, now still 50\% - of primary care services). Sufficient cancer care services have been a particular problem. Although additional national funds have recently been committed to expanding cancer care services, there remain difficulties in access to timely care, as well as to new cancer-fighting biologic pharmaceuticals. More broadly, in the post-2008-fiscal-crisis, information-revolution-driven world, Swedish county councils have had increasing difficulty keeping up with the rapidly changing international standard of medical treatment (Saltman, 2019).

Second: Considerable difference in the relative balance of public as against private sector responsibilities for owning, operating and managing these two countries' respective hospitals. 
A key observation is that in Singapore, the substantial majority of hospital operating and capital decisions, exactly like overall health care payment decisions, are not made by politically elected officials and/or permanently employed, politically hired, public sector bureaucrats. Instead, these provider operating decisions are made either by private sector individuals or by employees of a public sector corporation working under quasi-independent private sector accountability, in both cases in accordance with private sector decision-making criteria (albeit in both cases under state regulatory supervision).

Importantly, given the post-1987 Health Corporation of Singapore structure for all public hospitals, this absence of direct political decision-making in day-to-day operations takes place in public as well as private provider institutions (Phua, 2003).

Singapore: A central characteristic of the hospital system in Singapore is the major role of private ownership and management. To be sure, political authorities are responsible for steering a range of public financing subsidies [amounting as noted earlier to $53 \%$ of total operating revenues in 2016 (WHO, 2019)] to both public and private hospitals, as well as funding any operating shortfalls - after Singaporean citizens pay their share of hospitalization costs in these public hospitals with their medical savings accounts - in the overall income of the 15 public hospitals that make up the Hospital Corporation of Singapore. The government also sets care guidelines as well as strict policies on the use of budget surpluses (Haseltine, 2013). There is a clear distribution of differing clinical responsibilities among Singapore hospitals, with public institutions making up the major tertiary care and university teaching institutions, providing $80 \%$ of total hospital beds (Data.gov.sg, 2017).

Since both public and private sector hospitals operate under private-law-based, non-political management, they are able to develop their own business plans and to raise their own investment capital (from internal or external, e.g. investment sources), allowing them to make managerially and market-motivated decisions on investments in new capital equipment, new services and new employees (Phua, 2003). This gives both public and private hospitals considerable flexibility to innovate to meet the rapidly changing clinical standards of care and outcomes that accompany the current period of technological development.

Thus, although struggles over institutional decision-making between medical professionals and hospital administrators have a long history in all health systems, making them appear almost as inevitable (Young and Saltman, 1985), the added difficulty of negotiating directly with elected politicians over each budget item is not part of the annual funding or delivery process in either public or private hospitals in Singapore.

Sweden: The structure of hospital ownership, operation and management in Sweden is nearly entirely public sector in structure. There are only two small 40-bed private hospitals, and even these institutions sometimes rely on off-hours public sector specialists for their medical capacities (Anell et al., 2012). Recently, faced with high capital costs for new hospital construction, there have been several public-private partnerships (PPPs) developed around either expansions or new builds, which has included setting up a new private company (with partial public sector ownership) to operate and manage these new institutions. Although the New Karolinska Hospital in Stockholm is the largest of these PPP models, there also has been a new Children's Hospital in Goteborg (Queen Silvia's Hospital for Children, opening in stages 2018-2020), and an expansion of the central hospital in Angelholm in Skane County which opened in 2018. Beyond these examples, however, with the exception of one privately contracted public hospital in Stockholm County (Sct. Gorans), and despite an initial, now rescinded (Anell et al., 2012), increase in institutional self-management in some hospitals in some counties such as Stockholm (e.g. Danderyd and Huddinge hospitals), secondary and tertiary hospital capacity in Sweden continues to be owned and directly operated by elected county level politicians and their managerial appointees (Anell et al., 2012). 
This mostly public structure of hospital ownership, management and operation carries several implications for the efficiency and effectiveness of hospital services in Sweden. Proponents of the public sector view it being less expensive and more efficient than the private market (Dahlgren, 2014) contending that public ownership is more financially efficient [see also the planned market/public competition argument in Saltman and von Otter (1992)]. These proponents further contend that public sector operation creates a transparent structure for policy decisions about health care services, with public budgeting debates and a direct link between service delivery decisions in county council providers and the income-tied tax rate that citizens have deducted from their paychecks. Indeed, Swedish commentators and outside observers alike regularly note the advantages of the direct democracy aspects of how the Swedish health system is configured (Saltman, 2015a).

Conversely, others (and sometimes the same commentators following the fiscal austerity after the 2008 financial crisis) point out dilemmas at the operational and decision-making levels in politically run health systems. These critics point toward the inherent sluggishness and rigidity in service decision-making, especially regarding new procedures, technology and equipment, that appear to also be characteristics of wholly publicly administered health systems (Busse et al., 2002; Stubbs, 2016; Edwards and Saltman, 2017; Tjerbo and Hagen, 2018; Saltman, 2019). They worry about the high fixed costs of bureaucratically administered institutions and the sluggish time-consuming process of getting political decisions at either the institutional managerial or capital investment level (Kittelsen et al., 2008; Eijkenaar, 2012; Rehnberg, 2019). In a time of rapidly changing international standards for care provision, driven by the information revolution which impacts all organizational and clinical dimensions of health care provision, cumbersome political processes raise questions about the timeliness and quality of provider services in a politically operated health system similar to that of Sweden.

\section{Further observations}

As the above discussion highlights, the structural differences between a tax-funded European system similar to Sweden and the Medical Savings Account (MSA)-based Singapore model are substantial. Beyond financing differences of MSA-based frameworks noted, traditional tax-funded systems also have fundamentally different cultural and political as well as health sector organizational arrangements. To draw on the case study above, Sweden's 'folkhem' model, with its broad emphasis on governmental responsibility and a wide-ranging equality (jamlikhet) of position, situation and outcome of all individuals in society, is structurally quite different from the individual-tied, family-based framework of responsibility embodied in Confucian ethics.

Perhaps not surprisingly, Swedish experiments with semi-autonomous public hospitals [similar to those put in place in Singapore in the mid-1980s (Ramesh, 2008), which were introduced in several hospitals in Stockholm County in the early 1990s (Bruce and Jonsson, 1996)], were relatively quickly eroded by the lack of fit between semi-autonomous hospital decision-making and powerful county-politician-based policy and budgetary controls (Saltman, 2015a). Furthermore, politically, despite substantial health sector financial pressures, in 2014 the two key national political parties involved in setting up the then-incoming minority Social-Democratic-led national government agreed a four-page memo of understanding that called for the flat prohibition of any health sector actor earning surplus revenue - e.g. 'profit' - or introducing any system of New Public Management in publicly operated hospitals. The national government's Reepalu Report in 2016 codified this anti-profit perspective (SOU, 2016: 78).

This clear contrast between the institutional and operational health sector realities in Singapore as against those in contemporary Sweden suggests that efforts to transcend the structural and cultural boundaries that separate two such dissimilar countries would be difficult at best. Traditional path dependency theory as applied to health systems further reinforces this concern (Oliver and Mossialos, 2005). However health sector history also suggests that similarly major leaps in health system structure can in fact occur. Denmark shifted its health sector 
funding in 1970 from social health insurance to a tax-funded model, as did Portugal in 1979, Italy in 1978 and Spain in 1986, as well as UK in 1948. Conversely, many Central European countries moved from state-funded to a hybrid state-run form of social insurance, or in the case of Czech Republic, to regulated private insurance, in the early 1990s. As the recent, unsuccessful effort of Ireland in 2011 to shift from tax-funded to social health insurance - following on the similarly short-lived policy discussion in the UK in the late 1980s - suggests, this type of fundamental structural transition is difficult to engineer and implement.

One frequently noted caution in comparing Sweden's health care costs with those of other countries is that Sweden has proportionately both more elderly and more immigrants. Both groups are considered to be more resource-intensive than younger and/or domestic populations. As Table 3 indicates, Singapore does have a somewhat more favorable demographic profile for elderly, however immigration statistics - as noted earlier - are more difficult to compare. Moreover multiple factors go into elderly care expenses, making cost implications harder to determine. In Sweden, for example, (free) informal caregivers (typically family members) were estimated in 1997 to care for $70 \%$ of all home care patients (although carers did receive some indirect government benefits such as pension points) (Johansson, 1997).

A second comparative point is the contention that, although Sweden's health system is operated by elected local-based democratic councils, Singapore, whereas formally democratic with a representative parliament, is virtually a one-party state and thus 'not a democracy'. A discussion of the range of institutional options in structuring a democratic national government is more of a political science than a health policy topic. In this case, however, it is Singapore that makes available to its citizens more control and authority over how their health care money is spent, that allows them the freedom to retain those funds for present and future use, and whose health system structure enables patients increased choice over where and from whom they receive their medical services. Thus if a key measure of democratic government is the freedom of individuals to make decisions about important dimensions of their own life, in the health sector Singapore would seem to qualify.

\section{Conclusions and limitations}

By comparing two small-population national health systems - those of Singapore and Sweden this paper highlights several key elements of health system structure in developed countries of East Asia as against those found in tax-funded health systems in western Europe. Notable in this Asian-European comparison are substantial differences between Singapore and Sweden in (a) the percentage of health system funding that is privately as against publicly raised, and (b) the amount of public tax money per inhabitant spent in each health system. This second taxfunded figure - 2058 USD for Singapore as compared with 4770 USD for Sweden - represents a striking difference, and reflects a fundamentally different policy and cultural balance between collective public as against individual private responsibility for funding health care services.

Overall, the paper examines four linked policymaking dimensions of Singapore's health sector structure, each of which take on increased importance in the current period of persistent public sector funding shortages in Western Europe's tax-funded health systems, particularly in coping with these countries' increasing numbers of chronically ill elderly and elderly retirees:

(1) Singapore's predominantly individual-based funding framework costs half as much public money as does Sweden's approach for largely similar clinical services and outcomes (2058 USD as against 4770 USD)

(2) Singapore's health funding strategy deals affordably with the costs of long-term care services for the elderly, a major concern going forward for every Western European health system: $80 \%$ of Singaporeans carry their own privately paid (but government regulated and priced) long-term care insurance, and many purchase additional long-term care 
supplements; typically with these insurance premiums paid from the individual's mandatory health and retirement savings accounts.

(3) Surplus health care funds that accumulate in individual medical savings accounts in Singapore automatically roll over to those individuals' personal pension accounts (also publicly mandated and maintained), where the funds help pay for those individuals' retirement living expenses thus reducing public sector pension and elderly housing costs.

(4) Amounts remaining at death in both an individual's medical savings and personal pension accounts in Singapore are inherited tax-free by a member of the individual's family, and can be invested in the Singapore economy - what welfare state theorists have termed the 'productivist' model which has been a central element in East Asian economic development (Peng and Wong, 2010).

Given the weak economic prognosis for European economies in the post-COVID-19 period, the attraction of a potential Singapore-style re-allocation of funding between public and private sectors, and between health and long-term care and pensions, as well as potential efficiency gains in hospital management, suggest that Singapore's health sector policies could become increasingly interesting in the Swedish as well as in other Western European tax-funded health systems.

Longer term, European economic projections forecast continued economic weakness for several years beyond 2020 - reflecting the cumulative damage of COVID-19 coming in addition to economic weakness remaining from the financial crisis of 2008 (Giles, 2020). Since lower economic activity reduces public sector VAT and income tax totals, health sector funding implications for taxfunded systems will likely be considerable. Indeed, figures from quarter 2 for 2020 show the Swedish economy contracting by $8.6 \%$ (Rees, 2020), and the quarter 2 drop in overall Eurozone GDP of $12.1 \%$ makes this same point for other tax-funded countries in Western and Central Europe (Strauss et al., 2020). With a number of European governments facing pressure to assess their COVID-19-related performance, the hard reality of reduced public revenues will likely make more mixed health financing and service delivery solutions look increasingly attractive.

To be sure, the extent to which Singapore or other developed East Asian health systems might serve as potential models for Sweden or other Western European tax-funded health systems is a politically, economically, as well as culturally fraught question. Path dependency in health care systems - maintaining existing institutions and allocations has been shown to be particularly difficult to alter (Oliver and Mossialos, 2005; Saltman, 2015a).

Further research may help explicate complicated calculations for government policymakers regarding a range of issues including overall approaches to achieving demographic, geographic and socio-economic equity; the potential impact of private sector management tools inside publicly operated provider institutions; the potential links between private payment and demand suppression; as well as the precise impact of differing population distributions (old and young; also immigrant) on overall health sector costs and efficiency. Additional analysis may help develop differing governance models that can serve to support existing health sector provider configurations (Duran et al., 2011).

These and similar questions will involve complex data compilation and assessment which go beyond the capabilities of one article. As an example, analyzing the potential implications of elderly differences in immigration and population mix on overall health and social care costs in Singapore compared with Sweden will require additional economic and financial data about the current mix of collectively and/or medical savings account funded (formal) as against unfunded, informal caregiver provided long-term care provision in each country, particularly since informal caregiver provided home care is partly publicly subsidized in Sweden through several different municipal and national tax-generated accounts.

As this case comparison of Singapore and Sweden has demonstrated, the structural, political, economic and cultural dimensions of other East Asian and European countries would need to be unwound to effectively consider advantages and disadvantages of different structural alternatives 
to what continue to be common health sector dilemmas. Each tax-funded European country's situation will be unique, and the potential usefulness of an East Asian counterpoint will differ considerably.

Despite these and other comparative concerns, the confluence of lower total health system and much lower public sector health care costs combined with broadly equivalent clinical and health status outcomes in Singapore as compared with Sweden would appear to raise important questions that deserve careful further policy consideration in tax-funded European health systems generally.

Acknowledgements. The authors thank the journal's reviewers for their helpful comments.

\section{References}

Alesina A and Giavazzi F (2008) The Future of Europe: Reform or Decline. Cambridge, MA: The MIT Press.

Anell A, Glenngard AH and Merkur SM (2012) Sweden: Health System Review. Brussels: European Observatory on Health Systems and Policies.

Barkman C (2017) Personal communication.

Barr MD (2001) Medical savings accounts in Singapore: a critical inquiry. Journal of Health Politics, Policy and Law 26, 709-726.

Bruce A and Jonsson E (1996) Competition in the Provision of Health Care: The Experience of the US, Sweden, and Britain. London: Ashgate Publishing.

Buntin MB, Damburg C, Haviland A, Kapur K, Lurie N, McDevitt R and Marquis MS (2006) Consumer-directed health care: early evidence about effects on cost and quality. Health Affairs 25(Supplement 1), w516-w530. doi: 10.1377/ HLTHAFF.25.W516

Busse R, van der Grinten T and Svensson P-G (2002) Regulating entrepreneurial behavior in hospitals: Theory and practice. In Saltman RB, Busse R, and Mossialos E (eds), Regulating Entrepreneurial Behavior in European Health Systems. Buckingham, UK: Open University Press, pp. 126-145.

Busse R, Blumel M, Scheller-Kreinsen D and Zentner A (2010) Tackling Chronic Disease in Europe: Strategies, Interventions, and Challenges. Observatory Studies Series No. 20, European Observatory on Health Systems and Policies, Brussels.

Cooper Z, Craig SV, Gaynor M and Van Reenan J (2019) The price ain't right: hospital prices and health spending on the privately insured. The Quarterly Journal of Economics, 134, 51-107.

CPFB (2018) Central Provident Fund Board Annual Report. Singapore, Republic of Singapore: Central Provident Fund Board.

CPFB (2019) CPFB Schemes - Healthcare - MediSave. Retrieved from https://www.cpf.gov.sg/Members/Schemes/schemes/ healthcare/medisave

Culyer AJ, Maynard AK and Posnett JW (eds.) (1990) Competition in Health Care: Reforming the NHS. Basingstoke, England: MacMillan.

Cylus J, Figueras J and Normand C (2019a) Will Population Aging Spell the End of the Welfare State? A Review of Evidence and Policy Options. Brussels: European Observatory on Health Systems and Policies. Available at https://silvereconomyforum.eu/wp-content/uploads/2019/07/PolicyBrief_AGEING_2019_web.pdf.

Cylus J, Roubal T, Ong P and Barber SL (2019b) Sustainable Health Financing with an Aging Population: Implications of Different Revenue Raising Mechanisms and Policy Options. Brussels: European Observatory on Health Systems and Policies. Available at https://extranet.who.int/kobe_centre/sites/default/files/pdf/SustainableFinancing_Summary_0.pdf.

Dahlgren G (2014) Why public health services? Experiences from profit-driven health care reforms in Sweden. International Journal of Health Services 44, 507-524.

Data O (2019) Health Spending. Retrieved from https://data.oecd.org/healthres/health-spending.htm

Data.gov.sg (2017). Number of Hospital Beds. Retrieved from https://data.gov.sg/dataset/21d426ab-3a21-46ae-860299a5a1968593/download

Dody R (2014) High-deductible health insurance plans with health savings accounts: a policy review. SPNHA Review 10, $1-$ 11. doi: http://scholarworks.gvsu.edu/spnhareview/vol10/iss1/5

Donnelly L (2019). Most NHS Trusts missing cancer targets as waiting times soar. Telegraph.

DOS (2018) Population Trends, 2018. Singapore, Republic of Singapore: Department of Statistics, Ministry of Trade \& Industry, Republic of Singapore.

DOS (2019) Population and Population Structure. Retrieved from http://www.tablebuilder.singstat.gov.sg/publicfacing/ downloadMultiple.action?id=118

Duran A, DuBois HFW and Saltman RB (2011) The evolving role of hospitals and recent concepts of public hospital governance. In Saltman RB, Duran A and DuBois HFW (eds), Governing Public Hospitals: Reform Strategies and the Movement Towards Institutional Autonomy. Brussels: Observatory Studies Series 25, European Observatory on Health Systems and Policies, pp. 15-34. 
Edwards N and Saltman RB (2017) Re-thinking barriers to organizational change in public hospitals. Israel Journal of Health Policy Research 6, 8.

Eijkenaar F (2012) Pay for performance in health care: an international overview of initiatives. Medical Care Research and Review 69, 251-276.

Eriksson A, Isaksson D and Jovic V (2019). Reserapport - Delagations resa till Singapore, 20-22 Februari, 2019: Vinnova.

Genet N, Boerma W, Kroneman M, Hutchinson A and Saltman RB (eds) (2012) Home Care Across Europe: Current Structure and Future Challenges. Brussels: European Observatory on Health Systems and Policies.

Giles C (2020) Economists dispute B of E's 'bullish' prediction of V-shaped recovery. Financial Times (May 8, 2020).

Glaser WA (1991) Health Insurance in Practice: International Variations in Financing, Benefits, and Problems. Oxford, UK: Jossey Bass.

Ham C (2001) Commentary: values and health policy: the case of Singapore. Journal of Health Politics, Policy and Law 26, 739-745.

Haseltine WA (2013) Affordable Excellence: The Singapore Healthcare Story. Washington, D.C.: Brookings Institution Press.

Hood C (1991) A public management for all seasons? Public Administration 69, Spring 3-19.

Houtepen R and ter Meulen R (2000) New types of solidarity in the European welfare state. Health Care Analysis 8, 329340.

H.R.1. Medicare Prescription Drug, Improvement, and Modernization Act of 2003. Retrieved from https://www.congress.gov/ bill/108th-congress/house-bill/1

Hsiao WC (2001) Commentary: behind the ideology and theory: what is the empirical evidence for medical savings accounts? Journal of Health Politics, Policy and Law 26, 733-737.

Johansson L (1997) Decentralisation from acute to home care settings in Sweden. Health Policy 41(Supplement), S131-S143.

Kessler DP and McClellan MB (2000) Is hospital competition socially wasteful? The Quarterly Journal of Economics 115 , 577-615.

Kittelsen S, Magnussen J, Anthun KS, Häkkinen U, Linna M, Medin E, Olsen KR and Rehnberg C (2008) Hospital productivity and the Norwegian ownership reform. A Nordic comparative study. HERO Working Paper 10/2008, Oslo University.

Korpi W (1983) The Democratic Class Struggle. London: Routledge.

Landsorganization (1990) Nittiotals Programmet. Stockholm.

Li AJ (2020) Singapore's divisions are deepening amid the crisis. Financial Times (July 29).

Lindbom A (2001) Dismantling the social democratic welfare model? Has the Swedish welfare state lost its defining characteristics? Scandinavian Political Studies 24, 171-193.

McKee M and Busse R (2013) Medical savings accounts: Singapore's non-solution to healthcare costs. BMJ: British Medical Journal 347, f4797.

Medical Tourism Singapore (2020) Available at https://www.budgetdirect.com.sg/travel-insurance/research/medical-tourism-singapore

Modi N, Clarke J and McKee M (2018) Health systems should be publicly funded and publicly provided. BMJ 362 , k3580.

MOH (2007). Directives on provision of Information on Charges, Bill Itemisation and Option for filling out prescriptions in Medical/Dental Clinics. Retrieved from https://www.moh.gov.sg/licensing-and-regulation/regulations-guidelines-and-circulars/ details/directives-on-provision-of-information-on-charges-bill-itemisation-and-option-for-filling-out-prescriptions-in-medicaldental-clinics

MOH (2018a) About ElderShield. Retrieved from https://www.moh.gov.sg/careshieldlife/about-eldershield

MOH (2018b) ElderShield. Retrieved from https://www.moh.gov.sg/cost-financing/healthcare-schemes-subsidies/eldershield

MOH (2018c) ElderShield Supplements. Retrieved from https://www.moh.gov.sg/careshieldlife/about-eldershield/supplements

MOH (2018d) Government Health Expenditure and Healthcare Financing. Retrieved from https:/www.moh.gov.sg/docs/ librariesprovider5/default-document-library/healthcare-financing_esh-apr2019.xlsx?sfvrsn=bfb4ed93_0

Mossialos E, Dixon A, Figueras J and Kutzin J (eds) (2002). Funding Health Care: Options for Europe. Buckingham, UK: Open University Press.

OECD (2017) Health expenditure and financing Retrieved from https://stats.oecd.org/index.aspx?DataSetCode=SHA\#

Oliver A and Mossialos E (2005) European health systems reforms: looking backward to see forward? Journal of Health Politics, Policy and Law 30, 7-28.

Pauly MV (2001) Commentary: medical savings accounts in Singapore: what can we know? Journal of Health Politics, Policy and Law 26, 727-731.

Peng I and Wong J (2010) East Asia. In Castles F, Liebfried S, Lewis J, Obinger H, \& Pierson C (eds), The Oxford Handbook of The Welfare State. Oxford, UK: Oxford University Press, pp. 656-670.

Phua KH (2003) Attacking hospital performance on two fronts: Network corporatization and financing reforms in Singapore. In Preker AS \& Harding A (eds.), Innovations in Health Service Delivery: The Corporatization of Public Hospitals. Washington: World Bank, pp. 451-483.

PRC, T. C. G. o. t. P. s. R. o. C (2012) China Social Security System. Retrieved from http://www.gov.cn/test/2012-04/20/content_2118401.htm 
Preker AS \& Harding A (eds.) (2003) Innovations in Health Service Delivery: The Corporatization of Public Hospitals. Washington: World Bank.

Ramesh M (2008) Autonomy and control in public hospital reforms in Singapore. The American Review of Public Administration 38, 62-79.

Rees T (2020) Sweden suffers record plunge despite lighter lockdown. Telegraph, Available at https://www.telegraph.co.uk/ business/2020/08/05/sweden-suffers-record-plunge-despite-lighter-lockdown/?li_source=LI\&li_medium=liftigniter-rhr

Rehnberg C (2019) Vem vårdar bäst? En ESO-rapport om svensk sjukhusvård i ett jämförande perspektiv. (Who cares best? An ESO Report on Swedish hospital care in comparative perspective). Rapport till Expertgruppen för studier i offentlig ekonomi. SOU 2019:8

Rosenthal MM (1986) Beyond equity: Swedish health policy and the private sector. The Milbank Quarterly 64, 592-621.

Saltman RB (2015a) Structural patterns in Swedish health policy: a 30-year perspective. Health Economics, Policy and Law 10, 195-215.

Saltman RB (2015b) Health sector solidarity: a core European value but with widely varying content. Israel Journal of Health Policy Research 4, 1-7. doi: 10.1186/2045-4015-4-5

Saltman RB (2018) Health care systems in developed countries. In Jameson JL, Fauci AS, Kasper DL, Hauser SL, Longo DL, Loscalzo J, (eds), Harrison's Principles of Internal Medicine, 20th Edn. New York: McGraw-Hill Education, Part I, Chapter 5, pp. 27-32.

Saltman RB (2019) Structural effects of the information revolution on tax-funded European health systems and some potential policy responses. Israel Journal of Health Policy Research 8, 8.

Saltman RB and Cahn Z (2013) Restructuring health systems for an era of prolonged austerity: an essay by Richard B Saltman and Zachary Cahn. BMJ 346, f3972.

Saltman RB and Dubois HFW (2004) The historical and social base of social health insurance systems. In Saltman RB, Busse R, \& Figueras J (eds), Social Health Insurance Systems in Western Europe. London: Open University Press/McGraw-Hill Education, pp. 21-32.

Saltman RB and Figueras J (1997) European Health Care Reform: Analysis of Current Strategies. Copenhagen: World Health Organization.

Saltman RB and von Otter C (1992) Planned Markets and Public Competition: Strategic Reform in Northern European Health Systems. Buckingham, UK: Open University Press.

Saltman RB, Duran A and Dubois HFW (2011) Governing Public Hospitals: Reform Strategies and the Movement Toward Institutional Autonomy. Brussels: European Observatory on Health Systems and Policies.

SOU (2016). Ordning och Reda i Valfarden. Stockholm. Regeringen.se.

Strauss D, Cocco F and Bruce-Lockhart C (2020) Eurozone GDP suffers sharpest fall in 25 years. Financial Times (1 August).

Stubbs E (ed.) (2016) The Health of the Nation: Averting the Demise of Universal Healthcare. London: Civitas.

Sweden.se (2018) Healthcare in Sweden. Retrieved from https://sweden.se/society/health-care-in-sweden/

The Local (2018) How many work permits Sweden has granted so far in 2018, and to whom. (April 10) Available at https:// www.thelocal.se/20180410/sweden-work-permit-statistics-2018

Thomson, S., Figueras, J., Evetovits, T., Jowett, M., Mladovsky, P., Maresso, A. and Kluge, H. (2015). Economic Crisis, Health Systems and Health in Europe: Impact and Implications for Policy. Maidenhead: Open University Press.

Tjerbo T and Hagen TP (2018) The health policy pendulum: cost control vs. activity growth. International Journal of Health Planning and Management 33, e67-e75.

WHO (2019) Government schemes and compulsory contributory health care financing schemes (\% of current health expenditure). Retrieved from apps.who.int/nha/database

Winblad U, Blomquist P and Karlsson A (2017) Do public nursing home care providers deliver higher quality than private providers? Evidence from Sweden. BMC Health Services Research 17, 1-12. doi: https://bmchealthservres.biomedcentral. com/articles/10.1186/s12913-017-2403-0

World Bank (2020) https://data.worldbank.org/indicator/SH.XPD.GHED.CH.ZS.

Yeh M-J (2019) Exploring users' perceptions and senses of solidarity in Taiwan's National Health Insurance. Public Health Ethics 12, 1-14.

Yoong J, Lim WY and Lin L (2018) Singapore. In Legido-Quigley H \& Asgari-Jirhandeh N (eds), Resilient and People-Centred Health Systems: Progress, Challenges and Future Directions in Asia. New Delhi: World Health Organization, Regional Office for South-East Asia, Vol. 3, pp. 292-317.

Young DWY and Saltman RB (1985) The Hospital Power Equilibrium: Physician Behavior and Cost Control. Baltimore, MD: Johns Hopkins University Press.

Zakaria F and Lee KY (1994) Culture is destiny: a conversation with Lee Kuan Yew. Foreign Affairs 73, $109-126$.

Cite this article: Saltman RB, Yeh M-J, Liu Y (2022). Can Asia provide models for tax-based European health systems? A comparative study of Singapore and Sweden. Health Economics, Policy and Law 17, 157-174. https://doi.org/10.1017/ S1744133120000390 